\title{
日本内分泌学会東部部会総会講演抄録（II）
}

\section{II-1 山羊の処女泌乳に現はれる内外多重双極性平衡原理}

群大・教育学部 村岡 五郎

Estrogen, testosterone の相反する注射液を山羊に投与して, 処女泌乳を行い, 乳の成分の糖, 脂肪成分 の\%が相反して変化する関係を, 排尿されるホルモンの比から推定されるてとを実証せんとするもので, 此 の現象が, 山羊の間性と普通山羊に共通現象であるが, 而し泌乳量にわいては, 蛋白の\%に比例して増減す る関係上, 間性山羊と正常山羊において, estrogen, testosterone の処女泌乳量が, 遺伝的体質により逆にな るので，ての普遍原理を内外多重双極性平衡原理と唱える. Selye の stress を生化学上何が normal であ るかを規定する事によつて示さんとする為に対数函数で平衡状態変数を定量せんとする. 最終的には成長木 ルモンと性腺刺激ホルモンの双極性と $\mathrm{N} / \mathrm{G}$ の双極性の平衡関係を次の式で示す.

$\log \frac{\mathrm{N}}{\mathrm{M}}+\mathrm{i} \log \mathrm{L}+\mathrm{F}=\log \frac{\mathrm{G} . \mathrm{H}}{\text { T.S.H }}+\mathrm{i} \log \frac{\text { Gonad. } \mathrm{H}}{\text { Adrenal. } \mathrm{H}}=\mathrm{C} \log (\mathrm{A}+\mathrm{iB})=$ E.S.V

II-2 ラット下垂体前葉に分布する神経線維の電子顕微鏡的観察

群大 ・内分泌研・形態 小林 靖夫

ホルッマン系雄ラットの下垂体前葉をオスミウムにて固定し電顕的に検索中，数例の動物の前葉組織中に 神経線維が侵入しているのを観祭した。前葉の比較的太い血管の周国腔に, 無髄の神経線維の束がシュワン 細胞に取囲まれ，更に外側は基底膜で覆われているのが容易に発見された，線維内には卵円形のミトコンド リア，神経細管および直径約 $1,000 \AA$ の顆粒または小胞を合んでおり，顆粒の電子密度は中等度であるが， 小胞の中にはまれに有芯小胞として出現するものもみられた．その他，線維内には雲絮状の不定形物質が含 まれているが，いわゆるシナプス小胞は観察されなかつた。これら神経線維の前葉への侵入経路および腺細 胞に対する支配は明らかでない。

II-3 ラット，間脳一下垂体一性腺系に関与する中枢神経機序の解明

第四報 : MPO-ARG 系の神経活動と性ホルモン

横浜市大・第二生理 久保 勝知，川上 正澄

Rat そわける LH 放出と, 内側視系前野 (MPO) 一弓状核 (ARC) 系の神経興奮レベルとの協関活動 を知るため，Wistar 系成熟雌 rat を用い急性微小電極法により，ARG 発射活動に対する MPO 電気刺激 の影響をみた。 4 日性周期の Proestrus では，MPO 刺激により ARG 発射活動は比較的低い刺激開值で 刺激中促進したが， estrus では刺激開值がかなり上昇すると共に ARG 発射活動は抑制された。 この変化 と性ホルモン血中濃度との関係を, estrogen (E) 投与と progesterone (P) 投与去勢 rat で調べた結果, 性周期の proestrus の変化は $\mathrm{E}$ 優位の状態に，estrus の変化は $\mathrm{P}$ 優位の状態によるものと推測された。

以上から，E 優位状態では MPO-ARG の神経経路が促進すると共に，MPO 興奮により ARG 活動が高 まる様に働く。一方 P 優位では MPO から ARG 亿対する反応を遮断し，MPO 興奮により ARC 活動 が抑えられる様に神経活動が切り換えられるととが推測された。

II-4 マウスプロラクチン抗血清の血清学的性状

国立ガンセンター・農林省畜試 小杉山基昭，森 純一，長沢 弘

マウス・プロラクチン（MPL）抗血清を MPL の生物活性の抑制実験て使用する目的で作製し，その血 清学的性状ならびに生物学的作用の検討を行なつた．抗血清は鬼をMPL で免疫して作製した．本抗血清は 寒天ゲル内沈降反応で MPL のほか正常マウス血清 (NMS), 各種臟器抽出液とも反応したが, NMS およ び脾抽出液による吸収後は MPL および下垂体粗抽出液のみと反応した。下垂体ホモジネートをディスク電 気泳動した後, 寒天ゲル内で吸収抗血清と反応させたととろ，MPL に相当する位置にのみ沈降線の出現を 
認めた。ささに本抗血清は MPL のハト嗉のう反応を明らかに抑制した，以上の結果から，本抗血清は NMS および脾抽出液による吸収後は MPL と特異的に反応し，MPL の生物活性を抑制するてとが明らかとなつ た. さらに本抗血清を用いて各種動物のプロラクチンの反応を調べた結果, マウスとラットのプロラクチン が不完全交叉を示した。

\section{II-5 尿中 LH の Radioimmunoassay}

東北大 - 鳥飼内科 出村 博, 出村 黎子, 布川 喬, 馬場 英行, 三浦 清 沃度化および標準物質には 8,400〜 18,000/U/mg の高度に純化された HCG を用いた．抗体には粗製 HCG をウサギに注射して得た抗血清から小児尿抽出物および高度に精製された FSH によつて吸収したも のを用いた. 沃度化は chloramine $\mathrm{T}$ 法によつて行い Sephadex G-100 カラムによつて純化した. Bound と Free HCG-131I の分離には dextran coated charcoal 法を用いた。 尿を抽出しないで用いると，尿中 LH 值はみかけ上高值あるいは低值を示す傾向があるので, 抽出が必要と考朰れれた. 尿中 LH の抽出に は $5 \mathrm{ml}$ の尿を酶酸で $\mathrm{pH} 5.5$ とし $25 \mathrm{ml}$ の ethanol を加えて $-20^{\circ} \mathrm{C}$ に 3 時間放置して沈源させる操作を 2 度繰り返えす方法を用いた。本法による最終回収率は74.7\%であつた，ての方法によつて尿中 LH を測 定した結果, 正常男子では 2〜7 IU (2nd IRP-HMG)/24hr 亿分布し, panhypopituitarism Sheehan 症候 群では低值, 閉経婦人では高值を示した。尿中 LH 值と血中 LH 值との間には良好な相関が得られた。

\section{II-6 腫掦 ACTH の Radioimmunoassay とその臨床応用}

東北大・鳥飼内科 三浦 清, 出村 博, 出村 黎子, 布川 喬, 馬場 英行

目的 : Radioimmunoassay による腫瘍中微量 ACTH の検出法の確立とその臨床応用. 方法 : 組織 $5 \mathrm{~g}$ 程度を酢酸抽出し, Ambeilite IRP-64 による吸着後60\%酢酸で溶出し, ての乾固物を組織 $1 \mathrm{~g}$ あたり $1 \mathrm{ml}$ 相当の N/10HG1 で溶解した. ての $0.5 \mathrm{ml}$ に Dexamethasone 1 日 $8 \mathrm{mg}$ 投与中の健常者数人から得られ た血漿 $1.5 \mathrm{ml}$ を加え，てれを $25 \%$ ヒト血清アルブミン蛋白濃度を $8 \%$ 亿調整した。 その後酸・アセトン (1:40) 抽出, 冷アセトン沈澱, 硅酸 $50 \mathrm{mg}$ による吸着, 酸・アセトン・水 $(0.1: 1: 9)$ による溶出をへ て, Incubation そ供した. Bound と Free の分離は, Dextran coated charcoal を用いて行なつた. 結 果 : 副腎癌によつた Cushing 症候群の副腎癌組織など ACTH 非産生癌患者腫堭組織中には, 8例計20回 の椡定で， ACTH 活性は全く証明されなかつた。 AGTH 添加実験では，組織 $1 \mathrm{~g}$ 中少なくも $25 \mu \mathrm{U} の$ $\mathrm{ACTH}$ が有意にかつ特異的に検出出来た. 3 例の ACTH 産生腫煬例の癌組織中には, 極めて大量の AC TH が証明された.

\section{II-7 ラットにおける副甲状腺ホルモンの radioimmunoassay に関する研究}

東大・老年病学 藤田 拓男, 岡野一年, 折茂 肇, 大畑 雅洋, 吉川 政己

${ }^{125} \mathrm{I}$ 標識副甲状腺ホルモンの作製には CMC-PTH (3,000U.S.P. 単位/mg) を用い，Hunter-Greenwood の方法にしたがつた。 ${ }^{125}$ 標識副甲状腺ホルモンのB と F の分離には Dextran-coated charcoal を用いた。 副甲状腺ホルモンに対する抗体は，TCA-PTH (250U.S.P. 単位 $/ \mathrm{mg}$ ) $10 \mathrm{mg}$ を Freund の complete adjuvant とともに 2 週間間隔で 5 回モルモットに皮下注射するととにより作製した．副甲状腺ホルモンの標準 曲線の作製には GMG-PTH および Eli Lilly 社の Parathormone (100U.S.P./ml) を用いた. てれらを稀 秎後，抗体とともに 72 時間 incubate したのち，一定量 ${ }^{125} \mathrm{I}$ 一標識副甲状腺ホルモンを加え，48 時間後に Dextran-coated charcoal を添加して B と F を分離しその比を副甲状腺ホルモンの濃度に対応させた。 つぎ に，難溶性サルファ剤で腎障害を起すととが知られている Na-Sulfacetyl-thiazole を慢性投与したラットお よび両側腎摘出ラットの血清中副甲状腺ホルモンの radioimmunoassay を行い，若干の知見を得たので報 告する.

II-8 下垂体剔出ラットの骨発育および骨形成に関する硬組織学的研究 
て, 硬組織学的検索を行つた。脛骨の長径発育は, 剔出直後より漸次, 発育は抑制され，1週間後には，殆 ぞ発育の停止をみる。しるに，大腿骨の横径発育は，剔出後に外骨膜性発育は停止するが，内骨膜性発育は 非常に緩慢ではあるが持続する，ての剔出後発育した骨皮質を，X線マイクロアナライザーによって元素分 析を行うと， $\mathrm{Ca}, \mathrm{P}$ の量的変化はみられなかつた。次に，下垂体剔出後に，大腿骨中央部に皮下骨折を起 し，化骨の形成を検索した。その結果，正常対照群に比し，量的には少ないが，化骨の形成をみた。 以上の 結果より，下垂体特に成長ホルモンは，長径発育即ち軟骨性化骨には絶対的な影響を及すが，横径発育や化 骨形成即ち結合織性化骨には，影響力が少ないものと考えられる。

\section{II-9 性ステロイド及び成長ホルモンの下垂体摘除ラット成長に及ぼす影響}

虎, 門病院内分泌科 ・朝日生命成人病研究所 松崎 宸, 鎮目 和夫

諸種性ステイロドの成長に及ぼす影響については尚不明の点が多く，基礎的検討の報告も少い．てとに成 長ホルモンとの共同作用については殆んど知られていない. 我々は下垂体摘除ラットに於て成長ホルモン (GH) と性スティロドの両者を投与した時の, 体重増加及び肋軟骨 DNA 合成につき検討した. 体重 120〜 150g の雔猚ラットの肋軟骨をとり，Murakawa-Raben 法によつて thymidine $\mathrm{H}^{3}$ の DNA への取り込み を測定した．下垂体摘除ラットにヒト GH $50 \mu \mathrm{g} / \mathrm{day}, 4$ 日間投与すると，予期の如く体重增加も，DNA 合 成も促進された。 estradiol 10 40 $\mu \mathrm{g} /$ day，progesterone $100 \mu \mathrm{g} /$ day 4 日間の単独投与，或いは $\mathrm{GH}$ と同時 投与は全く無効であり, estradiol は GH 効果にむしろ抑制的であつた。一方, testosterone $100 \mu \mathrm{g} /$ day 投 与は単独では無効であつたが， $\mathrm{GH}$ と同時に投与すると $\mathrm{GH}$ 単独投与時に比し，著明な体重増加，DNA 合成促進がみられた。雌雄両性に於て思春期の成長のスパートは androgen によるのではないかと思われる。

\section{II-10 ヒト，モルモット，ラット脂肪組織における methoxamine の Lipolysis に} 及ぼす影響

虎, 門病院内分泌科 - 朝日生命成人病研究所 松崎 宸, 鎮目 和夫 東医歯大・第三内科 綿引 定清, 沼野 藤夫

我々は種々動物の脂肪組織にわける lipolysis 亿及ぼす種々の adrenergic 及び adrenergic blocking agent の効果につき報告してきた，今回は純粋な $\alpha$ adrenergic agent である methoxamine の効果につき 報告する，ヒト，モルモット及びラットの旁睪丸或いは後腹膜からえた脂肪組織を Rodbell の方法で脂肪 細胞とし，4\%のウシ・アルブミンを含む KRP 中で 2 時間 incubate し, glycerol 及び free fatty acids 放出を測定した。 epidephrine 或いは isoproterenol $0.01 \sim 0.25 \mu \mathrm{g} / \mathrm{ml}$ による lipolysis は 10〜100 $\mu \mathrm{g} / \mathrm{ml}$ の methoxamine 添加により著明に抑制される結果をえた。 ての結果は我々の仮説である $\alpha$ receptor は lipolysis 亿抑制的に働くという考光方とよく一致する. しかし上記の catecholamine と methoxamine の binding site に於ける competitive inhibition も否定出来ず今後の検討を要する.

II-11 合成 TRF (Pyro-Glutamyl-Histidyl-Proline Amide) と下垂体 cyclic AMP

$$
\begin{aligned}
& \text { 東大 ・第一内科 兼子 俊男, 斎藤 史郎, 岡博 } \\
& \text { 静薬大・生物薬品化学 矢内原 昇 }
\end{aligned}
$$

1969年 TRF の基本構造が解明されて以来， $100 \mathrm{~m} \mu \mathrm{g}$ の合成 TRF の静注により，シロネズミ血中 TSH が 5 分で約10倍に上昇し（Martin ら，1970）またヒトでも 100〜800 $\mu \mathrm{g}$ の静注により 10分で有意の血中 TSH の上昇を認めたととなど（Bowers ら，1970）が報告され，in vitro のみならず， in vivo でも合成 TRF によるTSH の分浪促進が確認された。一方 hypothalamic extract によるシロネズミ下垂体の adenyl cyclase, cyclic AMP の上昇と LH の分泌促進 (Zor, Kaneko ら，1969) などより, hypothalamic releasing factor の作用と下垂体 cyclic AMP との関連が注目されている. 今回我々は Pyro-glutamyl-HistidylProline Amide を合成し，その下垂体 cyclic AMP におよぼす影響を検討した結果，合成 TRF が下垂体 cyclic AMP level を上昇するととを確認した $(10 \mu \mathrm{g} / \mathrm{ml}$ 合成 TRF により下垂体 cyclic AMP は約 2 倍 そ增加する）ので, in vivo の成績も併せて，合成 TRF の下垂体 cyclic AMP level 亿およぼす影響を 
報告する.

II-12 合成 TRF (Thyrotropin Releasing Factor) に関する研究（第一報）

群大・第一内科 竹村 喜弘, 上原 昭夫, 女屋 敏正, 柁原 昭夫, 山田 隆司 七条小次郎

我々は, 合成 TRF (Thyrotropin Releasing Factor) Pyro. glu-His-Pro. $\mathrm{NH}_{2}$ を入手する機会にめぐ まれたので，実験成績の再現性が比較的高いとされるラッテを用い，甲状腺 $\mathrm{I}^{131}$ 放出及び甲状腺 Colloid Droplet 生成を観察した．合成 TRF を $5 \mu \mathrm{g}$ 乃至 $10 \mu \mathrm{g}$ をラッテに経静脈的に投与すると，50 $\mu \mathrm{g}$ 以上投 与群では，明らかに血中 $I^{131}$ の上昇を認め，その上昇は投与量に比例している. TRF 投与 2 時間前に $10 \mu \mathrm{g}$ の Thyroxine を投与しておくと，その TRF 効果は抑制され，乙のような点から合成 TRF は，精製 TRF と同様な性質のものと考えられた。，又，甲状腺 Colloid Droplet 生成は，TRF 投与群で著明に増加してい るととが明らかにされ，合成 TRF の下垂体一甲状腺系に対する特異的効果がさらに確認された。

II-13 in vitro でのインスリン負荷後のラット視床下部の GRF 活性

虎, 門病院・内分泌科 沢野 真二, 佐藤 晴子, 鎮目 和夫 東医雷大・第三内科 沼野 藤夫

iniulin 投与後のラット視床下部の GRF の動態を知る目的で, Wistar 系ラット11匹を 1 群として各群 に regular insulin $2 \mathrm{U} / \mathrm{kg}$ を静注し, 静注後15分, 30分, 45分に断頭屠殺して, その視床下部 (SME) の GRF 活性を in vitro 法で測定した. medium および下垂体の GH 含量は, radioimmunoassay で測定 した. 3 回の実験で, 生食投与ラットの SME は, 対照と比較して medium 中の GH 含量を有意に増加 せしめたが，insulin 負荷後の SME では GH の分歪促進効果は減少し，45分後の SME では，GH の増 加はみられなかつた。 incubation medium 中の下垂体の GH 含量は, 生食投与ラットの SME で増加す る傾向にあり, insulin 負荷後は減少して対照值に近ずく傾向にあつた。 てれらの成績は, insulin 低血糖 刺激によつて, 視床下部の GRF 活性が減少するととを示している.

II-14 アルギニン二重負荷時の血中成長ホルモン及びインスリン分泌増加の再現性について 虎, 閏病院・内分泌科 鎮目 和夫, 松崎 宸, 沢野 真二

各 4 名の正常男子と女子に朝空腹時アルギニンモノクロライド $0.5 \mathrm{~g} / \mathrm{kg} 30$ 分間点滴静注負荷を 2 時間の 間隔で 2 回行ない，その前後 30 分毎に 4 時間半にわたり血中インスリン及び $\mathrm{GH}$ を測定， 1 週間後に同一 被検者に同様の試験を行なつた。. 血中インスリンは点滴開始30分後に常に最高值を示し大部分の例で第 1 回 負荷後の方が第 2 回負荷後より高值を示し, 又 1 週間後の再検に於ても比較的良い再現性が認められた。一 方, GH の増加は時間的にも上昇度に於ても極めて様々でその最高值は点滴開始後 $30 \sim 120$ 分に散在し, 又 例によつては第 1 回負荷後には上昇せず第 2 回負荷後にのみ上昇, 例によつてはその逆の反応を示した. 此 の結果よりアルギニン負荷による血中 $\mathrm{GH}$ 分泌反応は同一個体に於ても条件により著しく異る事, 従つて アルギニン負荷試験の結果の解橎や反応の比較には特に注意を要すると思われる. 又，アルギニンの GH 分泌促進は何らかの物質を介するものと思われる.

II-15 成長ホルモンとインスリン分泌の相関アミノ酸およびペプチドにたいする

反応について

$$
\begin{gathered}
\text { 東大 - 第一内科 吉田 尚義, 斎藤 史郎, 阿部 薫, 兼子 俊男, 福島 秀夫 } \\
\text { 中村, 栄一, 清水 直容 }
\end{gathered}
$$

成長ホルモンとインスリンは物質代謝調節に重要な役割を有するホルモンであるが，両ホルモンの分泌は 相互に深い関連を有するのみならず，その他のホルモンの分泌状態によつて大きな影響をうける．かかる問 題を検討するために内分泌・代謝疾患患者に種々の負荷試験をおてない，乙の両ホルモンの分泌変動を追究 した. 甲状腺機能九進症の患者にはアルギニン負荷にたいする反応は正常人と変りはなかつたが，Cushing 症候群，肥満症の患者では，GH の反応は弱く，インスリンは過剩分泌を示した。一垂体機能低下症の患 
者では GH の分必は欠除し，インスリンの分珌は subnormal であつた. かかる所見は GH とインスリン の分泌が病態をはじめ多くの因子により支配されているてとを示してわり，ての点をさらに追究するため， $\mathrm{ACTH}$ とペプチドに対する反応も検討し報告する.

II-16 Acromegaly における成長ホルモン分泌一Dexamethasone 投与の影響 北大 ・第二内科 中川 光二, 堀内 淑彦, 真下 啓明

Acromegaly 患者 7 例に, dexamethasone $9 \mathrm{mg}$ /日を 2 日間投与し，その前後における血中成長ホルモン (GH) の insulin 低血糖に対する反応（insulin 試験）を篗察し次の結果をえた。（1） dexamethasone 投 与前の insulin 試験では，5例において正常人と同様または以上の反応（前值からの増加量）をみとめ， 2 例では，無〜低反応であつた。（2） dexamethasone 投与後の前值（安静空腹時值）は，上記の前 5 例にお いては著明に低下し，後 2 例では，不変〜むしろ上昇をみとめた。（3） dexamethasone 投与後の insulin 試験では，前 5 例において，反応は投与前と同様であつた，以上の結果から，acromegaly には，2つの型 または時期があり，一つは，主として GH 分泌調節レベルの量的異常により，他の主として GH 分泌系 の自律的分珌によるものと想像される.

II-17 先端肥大症の成長ホルモン分泌に及ぼす glucocorticoid reserpine および tegrekol の影響について

東北大・鳥飼内科 出村 黎子, 布川 喬, 馬場 貴行, 出村 博, 三浦 清 先端肥大症の 6 症例を対象とし, dexamethasone, reserpine, tegrekol 等の血中成長ホルモン (HGH) に対する影響を検討した. Glucocorticoid の HGH 分泌抑制作用はすでに報告したが，本症でも試験前夜 12時に dexamethasone 4.0mg を一度に脛に投与すると, 翌朝 4 例中 3 例で HGH の前值並びに insulin に対する反応の抑制を認めた．次に reserpine $2.0 \mathrm{mg}$ を 2 週間脛に投与すると，投与中の $\mathrm{HGH}$ の前值並 びに insulin 亿対する反応は 2 例中 1 例で抑制された。本例では HGH の早朝空腹時值は投与前の $80 \mathrm{~m} \mu \mathrm{g} /$ $\mathrm{ml}$ 前後から $20 \sim 30 \mathrm{~m} \mu \mathrm{g} / \mathrm{ml}$ 一と抑制され，休薬により再び急速に高值を示した。 $60 \mathrm{Co}$ 照射と合わせて再 投与し，同様な抑制効果をえた. tegrekol を 1 例に使用した結果では，HGH に対する抑制効果は認めら れなかつた，以上諸種薬剤の効果より，本症の成因に高位中枢の関与が示唆され，更に有効な非観血的治療 法についても手がかりをえた。

II-18 糖尿病における HGH分泌（第 3 報） - Triiodothyronine 及び Glucocorticoid 投与時の $\mathrm{HGH}, \mathrm{IRI}, \mathrm{FFA}$ 反応一

金沢大・第二内科 中林 肇，波佐谷兼綱，曰倉 教臣，西沢千恵子，能登 康夫 内田 健三, 森本 真平, 竹田 亮祐, 村上 元孝

糖尿病にわける成長ホルモン $(\mathrm{GH})$ の役割については種々の論議がなされてきたが，未だ一定の見解は ない，我々は前回の本学会において糖尿病 (一次性) 患者を対象に insulin-induced glucose intolerance, glucagon 負荷状態にわける HGH 分泌反応を検討し, 報告した。 今回は催糖尿因子の明確な二次性病糖尿 病における HGH 分泌と IRI, FFA の関係を知る目的で, 薬物的甲状腺機能六進, ステロイド過㮃状態を つくり,てれらホルモンの相互の動きを観察した.正常男子志願者 20 名に Triiodothyronine (150 $\mu \mathrm{g} /$ 日) 10 日投与群及び Predonisolone ( $30 \mathrm{mg} /$ 日) 10日投与群を設け, 洎物投与前後について, Arginine (1-arginine monochloride $0.5 \mathrm{~g} / \mathrm{kg}$ 体重）負荷による HGH, IRI, FFA の変動を比較した.

II-19 Clofibrate で治療された糖尿病患者の血中 Insulin の変動

総合太田病院・内科 群大・第一内科 下田 新一, 国吉南海夫, 下条 宏, 山本 邦宏 関健鏗, 福田均

Radioimmunoassay により血中の Immunoreactive Insulin (IRI) の測定が可能となり糖尿病を早期空 腹時血糖值 (FBS=Fasting Blood Sugar), ブドウ糖負荷試験（OGTT=Oral Glucose Tolerance Test) 或は 1 日尿中糖排泄量等より論ずると同時に IRI 值でも或程度糖尿病の診断が可能となつて来た。特に 
OGTT 時の IRI の変動を知るととが糖尿病の診断上極めて有役であるてとは今や良く知られている事実 である，そこで本研究では糖尿病における OGTT 時の血中 IRI の変化を調へ，糖尿病における血中 IRI の変化は，(1) OGTT 時正常值の低目の值を示すが，特に糖負荷に反応を示さないもの，(2) 糖負荷後 120 分以後に IRI の上昇を認めるもの，(3) 糖負荷後60分以内に IRI の急激な上昇を認めるが 180 分後空腹時 IRI 值より非常に高い值を示すもの，(4) 空腹時 $100 \mu \mathrm{U} / \mathrm{m} 1$ 以上の高い IRI 値を示し糖負荷後も少なくと も 180 分後迄 $100 \mu \mathrm{U} / \mathrm{ml}$ 以上の高い值を示すの 4 群に分類された。. とのうち Glofibrate で治療された糖尿 病の IRI 曲線は OGTT 曲線の正常化に伴い正常化した。

II-20 Clofibrate の血糖低下作用

総合太田病院 - 内科 群大 第一内科 下田 新一, 国吉南海夫, 下条 宏, 山本 邦宏 福田均, 関健鏗

高脂血症を伴つた軽症糖尿病の血中脂質を低下させる目的で Clofibrate を使用し, Clofibrate の血清 $\beta$ Lipoprotein, total Cholesterol, Triglycerides 低下作用を調べ, 同時に同一症例について, Clofibrate の $50 \mathrm{~g}$ ブドウ糖負荷試験（OGTT=Oral Glucose Tolerance Test）に対する作用を調べて見たととろ， Clofibrate がかかる軽症糖㽷病の血中脂質を正常化し，血糖值を下げ，OGTT 時の血糖曲線を正常化する ことが明らかとなつたのでその結果を報告する. 本研究に用いた症例は全部で15例で，うち 4 例は高脂血症 のみで糖尿症のない症例で，乙れを本研究の対照群とした。乙れら対照群の 4 例と糖尿病 11 例に 1 日 1500 $\mathrm{mg}$ の Clofibrate を投与し， 8 週間目迄その効果を追求した. 刘照群の $\beta$-Lipoprotein, total Cholesterol 及び Triglycerides 共に 4 週間の薬物投与で正常化したが血糖值には見るべき変化は表われなかつた。糖尿 病患者ではこれら脂質の正常化に次いで血糖值及び OGTT 曲線の正常化が見られた。

II-21 Prostaglandin $\mathrm{E}_{1}$ の脂肪組織代謝に対する作用

慈惠医大・阿部内科 佐野 隆志, 小山 勝一, 池田 義雄, 阿部 正和

Prostaglandin $\mathrm{E}_{1}$ の脂肪組織代謝に対する作用. ホルモン様活性物質としてのプロスタグランデイン $\mathrm{E}_{1}$ (以下 $\mathrm{PGE}_{1}$ ) そついて, 脂肪組織代謝に対する作用をインスリンのそれと比較検討した。 in vitro の実験 条件で, ラット副蛙丸脂肪組織からの遊離脂肪酸 (NEFA), グリセロールの放出, 脂肪組織のブドウ糖摂 取を測定した。.その結果, $\mathrm{PGE}_{1}$ ばインスリンと同様, 脂肪組織からの NEFA，グリセロールの基礎放出を 抑制するととが認められた. 又 $\mathrm{PGE}_{1}$ は，ノルエピネフリン，グルカゴンによる脂肪異化促進作用に拮抗 するととが分かつた。しかし， $\mathrm{PGE}_{1}$ の脂肪異化抑制作用とインスリンの脂肪異化抑制作用との間には，協 調作用は認められなかつた。更に $\mathrm{PGE}_{1}$ は，脂肪組織のブドウ糖基礎摄取に影響を与えないが，グルカゴ ン，ノルエピネフリンによるブドウ糖とりてみを促進するてとが認められた。

II-22 CBC に対する下垂体の影響について

朝日生命成人病研 川合 厚生

下垂体の血墏コルチコステロイド結合能 (CBC) に及ぼす影響を研究する目的でラットを用い両側副腎剔 出術及びェストロデェン投与によつて夫々 induce される高 CBC が, Hypophysectomy によつて如何な る影響を受けるかを調べた，CBC の測定は Doe \& Seal の方法に拠り，血漿サンプル $1 \mathrm{ml}$ にコルチコス

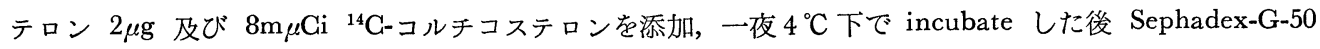
を用いて Gelfiltration を行なつた。両側副腎剔出ラット群では, 術後 1 週間目で著明な CBC の増加が認 められたが術直前に下垂体剔除を行なつたラット群では CBCの増加は起らず，対照值に止まつた．Hypox$\mathrm{Adx}$ ラットに $\beta^{1-24} \mathrm{ACTH} 0.1 \mathrm{mg} / \mathrm{day}$ 或いは BGH (NIH) $10 \gamma /$ day 1 週間注射しても CBC の上昇は 起らなかつた. 又, Estrogen 20\%/day を10日間注射すると明らかな CBC の増加が認められたのに対し, Hypox ラットでは之が認められず BGH の補充によつても CBC の上昇は induce されなかつた。

II-23 XX/XO mosaic を合併した giantism の一例

新潟大・第一内科 宮下 正弘, 佐々木英夫, 金子 兼三, 山田 幸男, 近藤 隆 
28才，女性，家族歴異常なし，出産満期正産，10才頃より急激に身長が伸び，18才で $172 \mathrm{~cm}$ となる．初 経 14 才, その後 4,5 回の月経後無月経となつた. 入院時身長 $175 \mathrm{~cm}$, 体重 $54.5 \mathrm{~kg}$, 知能正常, 鼻, 口 唇等軟部組織肥厚著明, 両側拇指短少, 乳房発育不良, 性毛男性様で全身多毛の傾向あり．外性器異常な し，早朝空腹時血中成長ホルモンは常に $30 \mathrm{~m} \mu \mathrm{g} / \mathrm{ml}$ 以上で，glucose に抑制されず，Arginine Insulin 刺 激に異常反応パターンを示す. 尿中 17-OHCS 正常, 17-KS やや高值, AGTH 試験反応正常であるが, SU 試験で低反応，BMR，RSU， ${ }^{131} \mathrm{I}-$ Uptake いづれも機能低下を示し，TSH に反応したてとより二次性 甲状腺機能低下が浔められた。尿中 Gonadotropin $16 \ll 32$ m.u.u. と高い. 試験開腹で, 子宮正常大, 卵巣 は両側肥大し，多曘胞性で被膜肥厚し，Stein-Leventhal Syndrome を疑われた。. Sexchromation $25 \%$ と 女性型, Karyotype はxx/xo mosaic であつた.

II-24 急性ポルフィリン症の内分泌機能異常について

新潟大・松岡内科 佐々木英夫, 金子 兼三, 山田 彬, 田中 直史, 宮下 正弘 佐藤 幸示, 常山 秀夫

新潟県立新発田病院 真山 俊

急性ポルフィリン症25例（急性間歇性ポルフィリン症15例，肝性コプロポルフィリン症10例）50回の発症 につき内分必機能異常を検討したので報告する。発症時低 $\mathrm{Na}$ 血症, 低 $\mathrm{Cl}$ 血症, 乏尿, 高比重尿が多く, Uosm/Posm も高く, 水負荷によつても尿は稀釈されず, ADH の分泌異常が窺われた. HGH は50g OGTT で paradoxical response を示し, Insulin 試験でも過剩反応であつた. 血中 cortisol, 尿中 17-OH, 17-KS とも高値を示すものが多く, 血中 cortisol の日内変動の異常, AGTH 試験の過剩反応も多く, 2 例で測定 した血中 AGTHも高值を示した。 また，発症と平行した乳汁分泌もみられ，HGH，AGTH，prolactinな ぞの過分泌が推測された。 てのほか, 尿中 Epinephrine, Norepinephrine, VMA も高值の例が多くみられ たが，甲状腺機能は正常であつた．乙れらの変化は寬解期には全て正常となつており，本症の発症機構と関 連した広汎な間脳下垂体機能異常が推測された。

II-25 ステロイド投与により尿崩症の軽快したと考えられるザルコイドーシスの 1 例

新潟大・松岡内科 尾崎 信紘, 佐藤 広則, 浜斉, 奈良 芳則, 近藤 隆

ザルコイドーシスにおいて尿崩症を呈する事は比較的稀で, 本邦においても少数例の報告を見るのみであ るが，最近ステロイド投与によつて尿崩症症状の軽快を見た 1 例を経験したので報告する. 患者は 50 才の農 婦. 44年10月頃より多飲, 多尿が出現, 尿量は 7000 9000ml/day で脱水試験にて U/P =0.68 ピメレシン に反応し真性尿崩症であつた. 胸部レントゲンで BHL を認め, クバイム反応陽性, 眼科的にもザルコイド ーシスの所見が認められた。 内分泌機能検査ではメトピロンテストに反応不良で, 下垂体予備能の低下が認 められた。 トルコ鞍は異常なし，甲状腺機能は正常であつた。 ステロイド及び，クロロペロパマイド投与に より $\mathrm{CH}_{2} \mathrm{O}$ の陰性化を見た，ステロイド単独投与に切り換えたが，尿量増加は見られなかつた．乙の症例 ではステロイドが尿崩症に対して効果があつたのではないかと考えられる.

II-26 多尿を主訴とする 6 症例

東医大・第三内科 梅原 千治, 杉本 民雄, 住谷 亮逸, 今井 竜雄, 小林 成价

口渴，多飲，多尿を主訴とする疾患には，先天性腎性尿崩症，心因性多飲症，真性尿崩症等があげられる. 我々は上記の症状を主訴として入院した 6 症例について, 入院時所見, 経過, 検查, 治療, 退院後の経過を 報告したい. 対象は男 5 例, 女 1 例で, 1 日尿量は 3.8 乃至 $10.6 l$, 尿比重は 1.025 を示したものもあるが 他は 1.020 以下であつた，末梢血液検查では， 1 例が軽度の貧血を示した．他は異常はなかつた，Carter Robbin's Test を行い 3 例で尿量の娍少を見，他の 3 例では尿量の減少をみなかつた. Vasopressin に対す る反応では， 6 例中 3 例で反応がみられ，他の 3 例では尿量減少効果を見なかつた. 以上の 6 例は，入院時 所見より心因性多尿症 3 例, 真性尿崩症 3 例で, てれらのうちわけは, ザルコイドージス, 脳腫癔, 結核性 路道莫炎の各 1 例であつた. 今回は，予後調查を行いてのうち 5 例について回答を得たのでその成績をのべる. 


\section{III- 1 前立腺の testosterone- $5 \alpha$-reductase}

$$
\begin{aligned}
\text { 群大 ・泌尿器科 島崎 淳, 山中 英寿, 古谷 信雄, 大木由美子, 永井 久子 } \\
\text { 志田 圭三 }
\end{aligned}
$$

我々は数年来ラット前立腺腹葉 testosterone- $5 \alpha$-reductase を研究した結果, 本酵素活性が aging により 影響を受けるとと，及び成熟ラットの本活性が去勢により低下， testosterone 投与により増加するてと等を 見出し，既に発表して来た（Endocr. Jap. 16，453，1969 及び．17，175，1970)。今回はその後判明せる次 の点について報告する．1. 本醉素活性が去勢後 $5 \alpha$-androst-1-ene-17 $\beta$-Ol-3-one によつても增加するて と. 2. 本䣼素の前立腺細胞内の局在について. 既に我々は本酵素が半分以上核分画に存在するのを報告し たが，今回はその詳細と醳素の性質について発表する.

\section{III-2＼cjkstart䁄丸の Steroid-7 $\alpha$-hydroxylase の分布及びその性質}

放医研・薬学 稲野 宏志, 玉置 文一

昨年の本学会において, $7 \alpha$-hydroxylase がラットの辠丸に存在している事を報告した. 今回は, $7 \alpha$-hydroxylase の分布とその性質について報告する，X線をラット辠丸に局部照射して精子形成を破壊した笠丸 でも androstenedione から $7 \alpha$-hydroxyandrostenedione を生合成する事から $7 \alpha$-hydroxylase は睪丸の 間質細胞に存在すると思われる。 また, 睪丸のホモジエーネートを細胞分画して mitochondria, microsome および superna tant fluid を得, 細胞内分布を調へた結果 $7 \alpha$-hydroxylase は microsomal fraction に局 在し，さらに microsomal fraction を粗面および滑面小胞体に分離して submicrosomal 内分布を調べて結 果, $7 \alpha$-hydroxylase は滑面小胞体に局在していた。一方， $7 \alpha$-hydroxylase の至適 $\mathrm{pH}$ および至適温度は，

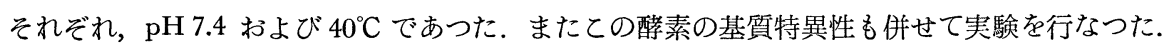

III-3 Androstenedione の $19 \mathrm{OH}$ 化, 及び Estrone への変換

$$
\text { 放医研・薬学 王欄, 玉置 文一 }
$$

馬睪丸における 19OHase Aromatase は Ms 分画に局在している. 中性ステロイドから Estrogen への 変換には分子状の酸素と NADPH が必要であり，その第 1 段階として $19 \mathrm{OH}$ が想定されている．馬辠丸 の Ms 分画を使用して, ${ }^{14} \mathrm{C}$-Androstenedione を基質として, 気相を $\mathrm{Ar} . \mathrm{O}_{2}, \mathrm{CO}$ とし, cofactor を NA DPH, NAD と変えて, それぞれ incubation を行い, Estrone, 19OH-Androstenedione の生成の量的関 係を調べた。 又 $\mathrm{O}_{2}, \mathrm{NADPH}$ 存在下で Androstenedione を基質として, 反応時間に対する 19OH-Androstenedione Estrone 等の生成率の変化を研究した。尚, 人胎盤の Ms 分画の $19 \mathrm{OHase}$, Aromatase 飞 ついても比較検討した.

\section{III-4４才の性早熟患児睪丸にわける androgen 生成}

東医菊大 ・ 泌尿科 大島博幸, 石渡 大介, 玉木 綾子

4 才ですでに睅丸容積は両側 $15 \mathrm{ml}$ 以上に達し, 組織学的に造精機能の開始を認めたが, 二次性徵の発現 は軽度であつた患児についての検索成績を報告する，尿中 FSH 排泄量は約 $200 \mu \mathrm{g}$ (eq NIH-FSH-S $) / 24 \mathrm{hr}$ と高值を示したが，LH 排泄量は約 $50 \mu \mathrm{g}($ eq NIH-LH-S 8 ) $/ 24 \mathrm{hr}$ であつた。 ての等丸を生検し，その Cellfree homogenate を用いて Steroid 代謝を検索した。17 $\alpha$-hydroxylase, G17-C20lyase の活性は明らか記認 められたが $3 \beta$-hydroxysteroid dehydrogenase の活性は検出されず, 17 $\beta$-hydroxysteroid dehydrogenase は極めて高い活性を示した。

III-5 尿中 Testosterone 及び Epitestosterone の日内リズム

$$
\begin{aligned}
& \text { 北大・第二内科 岡本 正敏, 中川 光二, 堀内 淑彦 } \\
& \text { 北大・第一生理 谷森 潔, 伊藤 真次 }
\end{aligned}
$$

尿中 17-Ketosteroids (17-KS) の測定により，副腎皮質機能に日内リズムがあることを1943年 Pincus に よつて報告されて以来, 血中 Cortisol, 尿中 17-Hydroxycorticoids (17-OHCS), 血中 ACTH などの測定 により，いずれも日内りズムの存在が多くの報告者によつて認められている，しかし，性腺機能については 
血中 Testosterone, 血中 LH などの測定により，今日尚，必ずしも日内りズムの存在についてははつきり していない. 又尿中 Testosterone 值より日内リズムの存在を検討した報告は見当らない. 我々は，正常健 康男子12名の 1 日 6 分割, 各 4 時間尿により, 尿中 Testosterone 及び Epitestosterone 值を Gasliquid chromatography により測定し, 17-KS 值と共に, 性腺機能の日内リズムの存在について検討した.

III- 6 ラット弤娠黄体の電子顕微鏡的研究

群馬大学内分泌研究所 黒住 一昌

弤娠 $3 ， 5 ， 8 ， 12 ， 16 ， 19 ， 21$ 日のラット卵巣をグルタールアルデヒド, オスミウム酸二重固定後, 主と して黄体に注目して電顕観祭した，黄体細胞は妊娠 3 ～ 5 日では, 遊離りボゾームに富むが, 小胞体の発育 は悪く, 胞状の小胞体が散在し，その大部分は部分的に粗面である. 完全な滑面小胞体がある一方, 数層の 平行層板状の粗面小胞体も出現して来る. 滑面小胞体は妊娠日数の增加とともに増量し, 網状の細管より成 る. 妊娠後半では人黄体に知られている folded membrane complex がみられる。ゴルジ装置の発達がよく， lysosome の他径 $100 \mathrm{~m} \mu$ 前後の暗調球形顆粒を産生する. ての顆粒の細胞外放出も時としてみられる. 糸粒体はしばしば変形し，カップ状に重なり，特殊な糸粒体封入物を有することが多い，少数の細胞に複雑 な構成の核封入体がみられた。

III-7 人月経及び弤娠黄体に於ける Pregnenolone- $7 \alpha-{ }^{3} \mathrm{H}$ 及び Progesterone- $4-{ }^{14} \mathrm{C}$ の Estrogen への変換について

群大・産婦人科 品田 孝夫 Dept. Obst. \& Gyne., Univ. of Calif., K.J. Ryan

人黄体が Progesterone 及び Estrogen を合成するととは現在広く認められている. 人黄体で Pregnenolone が Estrogen に変換される際， 44-3-one の経路を経るととが示されたが (Ryan 1963) まだ不確実で ある. 今回等モル量の Pregnenolone-7 $\alpha-{ }^{3} \mathrm{H}$ 及び Progesterone-4- ${ }^{-14} \mathrm{C}$ を Substrate に用い, in vitro の Incubotion 実験を行つて，その Metabolites を分析するととにより，人黄体では， $\Delta^{5}$-3 $\beta$-ol Intermediate 或いは $\Delta^{4}$-3-one Intermediate の何れが Estrogen 生合成に関与しているかを検討した。 その結果 Metabolite ${ }^{3} \mathrm{H} /{ }^{14} \mathrm{C}$ 比を比較するととにより，人の月経及び弤娠黄体の Estrogen 生合成の主要経路は Pregnenolone $\rightarrow$ Progesterone $\rightarrow 17 \mathrm{OH}$ Progesterone $\rightarrow$ Androstenedione (or Testosterone) $\rightarrow$ Estrone 及び Estradiol であると考えられる.

III-8 分婏時のストレスと母体血中エストロゲン值の関連について

東京警察病院・産科婦人科 桑原 慶紀, 鬼原 勝之, 荒井 清 妊娠中大量に産生されるエストロゲンの前駆物質は大部分胎児副腎に由来しているととが in vitro 並び に in vivo 実験によつて明らかとされて来た。ての大量に分修されるエストロゲンの持つ臨床的意義はも とよりその産生調節機序に関しては未だ不明の点が多い，我々は先に，胎児下垂体一副掯系を直接刺激或は 抑制した場合のエストロゲン值の変動につき報告したが，今回分婏経過にともなう母体末梢血中エストロゲ ン值の変化を追求し，いささか知見を得たので報告する．陣痛開始後子宮口開大が始まつた時点と，ほぼ全 開大となり分婏第期に移行する時点とに於いて同一産婦15例につき末梢静脈血を採取測定した．初産婦に 於て $\mathrm{E}_{1} 56 \% ， \mathrm{E}_{2}$ 14\%， $\mathrm{E}_{3} 16 \%$ と夫々分婏経過にともなつて増加したが，経産婦に於ける変化はそれ程著 明でなかつた，分婏第 I：II期の児に対するストレスが大きいと考えられる時期にステロイド産生に何らか の変化が起るととが示唆された。

\section{III-9 Plasma 11-OHCS の日内変動テストに依る間脳性月経周期異常の診断}

群大・産婦人科 O佐藤 恒治, 佐藤 有夫, 石川 順子, 松本 清一 24時間にわたる神経生理的現象である Plasma 11-OHCS の日内変動は視床下部機能の障害をより早く広 い部分にわたつて示すといわれるが，本テストを20例の周期異常患者で検討した．同時に全例に経夜睡眠脳 波, 尿 中FSH, estrogen, 17-KS, 17-OHCS の測定も行つた. 20例のうち Plasma 11-OHCS の日内変動が異 
常であつたものは13例で，睡眠脳波では14例に異常波が見られた．とのうち1例をのぞいて全例で Plasma 11-OHCS の日内変動でも異常型を示した，尿中 17-KS，17-OHCS はいづれの患者でも正常值を示したが， 尿中 FSH では FSH が異常高値を示した例では 11-OHCS の日内変動に異常が認められなかつた. 更に Plasma 11-OHCS の異常例に clomiphene 或は 1-(P-chlorophenyl)2-methyl-2-aminopropane hydrochloride を投与して排卵が起つた例で再度 Plasma 11-OHCS の日内変動をみると正常型に戻つた. 以上から 本テストに依つて間脳性周期異常を早期に且つ簡単に診断できると思われる。

\section{III-10 ${ }^{3} \mathrm{H}-\mathrm{NE}$ による生体内カテコールアミン代謝に関する研究}

岩手大・木村内科 中島 泰彦, 似内 靖夫, 井上一彦

本態性高血圧症および甲状腺機能六進症において NE 亿対する反応性が正常者にくらべ大であるととは 知られている事実である. ての反応性の相違がかかる機序によるのか未解決の問題が多い. 今回私共は正 常者 4 名, 未治療の本態性高血圧症患者 4 名, 未治療の甲状腺機能元進症患者 6 名に ${ }^{3} \mathrm{H}-\mathrm{NE} 300 \mu \mathrm{Gi}$ を静 注，静注後 1 時間， 3 時間， 6 時間，24時間，48時間，72時間と経時的に NE およびその代謝産物である NM, DHMA, MHPG, VMA を Axelrod の方法に準じて測定し次のでとき結果をえた. 本態性高血圧症 患者においては $\mathrm{NE}$ 注入後 6 時間目までの尿排泄量および代謝パターンは正常者とほぼ同様の值を示すが, 24時間以降の尿中排泄量は正常者にくらべ低值をとり，しかも，VMA 排泄量比の増加を認めた. 一方甲 状腺機能六進症患者においては全経過を通じて尿中排泄量は正常者より低值を示し，さらに24時間以降の VMA 排泄量比の増加を認めた。 この事実は両疾患において NE の組織へのとりてみ過程, 再分泌および その代謝過程に正常者と異る点が存在することを示す成績であると考える.

III-11 ビタミンD抵抗性くる病の 3 例

国立小児病院内分泌代謝科 ○田苗 綾子, 桑島 克子, 日比 逸郎

ビタミンD低抗性くる病の病型における多様性は周知のととであるが, 同時にその治療法も症例により異 る. 長期療法が必要であるにもかかわらず，代謝の面より一様でなく困難な問題に遭遇するてとが多い. 治 療の前後における, カルシウム・燐代謝および尿中総ハイドロキシプロリン排泄パターンを 3 例の異る経過 を示す例について報告する。カルシウム負荷により，尿中ハイドロキシプロリン排泄が減少するが，その程 度は尿中燐排泄減少率と平行した. 適切な治療にてコントロール良好のものは治療前増加していた尿中ハイ ドロキシプロリン排泄は正常化した．一方，治療が行過ぎ高カルシウム血症を伴う例では尿中ハイドロキシ プロリン排泄の著明な低下をみた．治療が不充分な例では常に尿中ハイドロキシプロリンの著增をみ，血中 アルカリフォスファターゼ值と相関していた。 てのようにコントロール困難な例は血清カルシウム, 燐值の 正常の例であつた.

III-12 副腎皮質ステロイドの投与により，副甲状腺発症を回避し得た原発性副甲状腺癌

東北大・鳥飼内科 ○古川洋太郎, 葛西 外科, 的場 直矢

骨病変を主徵とした原発性副甲状腺機能六進症の著るしい高 $\mathrm{Ca}$ 血が，副腎皮質ステロイドの投与に反応 し, 副甲状腺発症を回避し得た原発性副甲状腺癌を報告する. 症例は37才，家婦. 主訴は半年前より次第に 增覀してきた両側膝関節痛, 背痛, 歩行障害. 全身の骨レ線に脱灰所見と骨膜下吸収が著るしく, 右大腿骨 に褐色腫がみとめられた。 血清 Ca 17.4mg/dl, P 1.5mg/dl, Al. P-ase 71.6K.A. 1 日 10 に におよぶ多尿と， 低 $\mathrm{K}$ 血, 高尿酸血をともなつた. 左頸部に桜桃大の腫瘤を触れ, 75 Se-selenomethionine による Parathy-

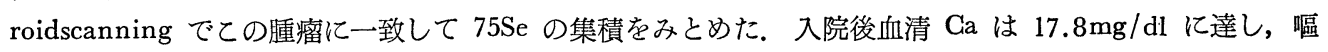
気を訴える様になつた. Prednisolone $40 \mathrm{mg}$ を経口投与した所血清 Ca は次第に低下し，1 週後には 13.0 $\mathrm{mg} / \mathrm{dl}$ となると共に臨床症状も著明に改善した。 入院 3 週後, 重さ $9.9 \mathrm{~g}$ 甲状腺, 食道筋層への浸潤をと もなつた副甲状腺癌を摘出した，術後の経過はほぼ良好である.

III-13 低マグネシウム血症ラット腎に対する副甲状腺ホルモン作用

東大・第一内科 ○永田 直一，兼子 俊男 
イオン環境の変化が副甲状腺ホルモン $(\mathrm{PTH})$ の生理作用の発現に影響することが知られて来たが，マグ ネシウム $(\mathrm{Mg})$ イオンも, PTH の骨吸収促進作用を変化させることや，そのヒトにおける欠乏が PTH 投与によつて起る尿中 cyclic AMP の排泄増加, リン酸尿効果を抑えるととが報告されている. とくに腎 に対する PTH 效果と $\mathrm{Mg}$ の関連を知るため $\mathrm{Mg}$ 欠乏食を投与して, 低 $\mathrm{Mg}$ 血症ラットを作り, in vivo に PTH を投与した際の腎実質中の cyclic AMP 量, Mg free のメジウムでインキュベートして PTH を 添加したさいの副切片中の cyclic AMP 量, PTH 灌流による尿中 cyclic AMP 量およびリン排泄量を欠 そ群と対照群で比較した，充分量の PTH では両者に差を梕めなかつたが，更に微量の PTH に対する反 応性を検討したので報告する。

III-14 Addison 病と糖尿病の合併例

東北大 - 鳥飼内科 ○馬場 英行, 奥山 牧夫, 出村 黎子, 織内 素生, 布川 喬
出村 博, 三浦 清

結核によると推定される Addison 病で, 後に糖㽷病の合併した 1 症例を報告する。症例：62才，女性. 主訴は色素沈着，糖尿. 家族に Addison 病も糖尿病もなく，血族結婚もない. 24才時に腹膜炎に罹患. 不妊. 47才頃より，皮膚色素沈着，倦急感等が出現. 51才の時, Addison 病の診断のもとに, Cortisone acetate 1 日 1 錠による補充療法を受けたが，服薬は不規則であつたという。61才の時初めて尿糖を指摘さ れ，患者はその半年程前から Cortisone 服用を中止しており，一時軽快した色素沈着も再度増強. 現症 : 身長 $139 \mathrm{~cm}$ ，体重 $49.5 \mathrm{~kg}$. 血圧は $120 / 80$ で，皮膚色素沈着も著明．レ線上，腹部全般に，又右副腎部に も石灰化像が示唆された。血中および尿中副腎糖質ステロイド值並びに Cortisol 分泌量はいずれも低下し， 外因性 ACTH にも無反応. 尿糖量は 1 日 $10 \mathrm{~g}$ 程度, 空腹時血糖は $112 \mathrm{mg} / \mathrm{dl}$ を越えなかつたが, GTT では明らかな糖尿病型であつた，甲状腺機能は正常. Addison 病と糖尿病との関係は不明である.

III-15 Addison 病患者に対する Dexamethasone 療法の有効性について

東北大・鳥飼内科 出村 博, 市川 喬, 馬場 英行, 出村 黎子, 三浦 清

Addison 病患者 4 例に，十分量の NaCl を投与しながら dexamethasone による治療を試みたとてろ， 色素沈着の改善が著しく, 体重が増加した. 第 1 例は47才, 女. Cortisone acetate 1 日 $37.5 \mathrm{mg}$ (朝 $25 \mathrm{mg}$, 昼 $12.5 \mathrm{mg}$ ）の補充によつても色素沈着の改善は思わしくなく, 血漿 ACTH 值は治療前 $980 \mu \mu \mathrm{g} / \mathrm{ml}$ から $178 \sim 600 \mu \mu \mathrm{g} / \mathrm{ml}$ の高值に止つた. dexamethasone $0.75 \mathrm{mg}$ （朝 $0.5 \mathrm{mg}$, 昼 $0.25 \mathrm{mg}$ ）投与に切り換えたと ころ，1 ケ月前後から色素沈着は著明に改善し，3 ケ月半後の血漿 ACTH 值は not detectable であつた. 第 2 例は36才，女. Cortisone acetate 1 日 $25 \mathrm{mg}$ （朝, 昼 $12.5 \mathrm{mg}$ づつ）を dexamethasone $0.5 \mathrm{mg}$ （朝， 昼 $0.25 \mathrm{mg}$ づつ）に切り換えたととろ，色素沈着が改善し，血漿 AGTH 值は $100 \sim 120 \mu \mu \mathrm{g} / \mathrm{ml}$ から 20 $\mu \mu \mathrm{g} / \mathrm{ml}$ 以下に低下した。 他の 2 例は43才および25才女子で, 何れも Hydrocortisone 1 日 $20 \mathrm{mg}$ (朝, 昼 $10 \mathrm{mg}$ づつ) を dexamethasone $0.5 \mathrm{mg}$ （朝, 昼 $0.25 \mathrm{mg}$ づつ）に切り換えたととろ, 1 ケ月前後より色素 沈着の著しい改善が認められた。 Addison 病患者における dexame thasone 療法の有効性が確認された.

III-16 Steroid Withdrawal Syndrome の 2 例

慈患医大 ・上田内科 南 貞夫, ○伏谷 靖, 上田 泰 ネフローゼ症候群の副腎皮質ステロイド療法中，治療の一時中断により steroid withdrawal syndrome を経験したので報告する. 症例は23才と21才の女性でいずれも糸球体腎炎に由来するネフローゼ症候群であ る. 症例 1. 昭和44年 1 月より気管支喘息, 10月よりネフローゼ症候群にて昭和 45 年 5 月まで副腎皮質ステ ロイドを服用していたが, 入院前日に中止. 入院 5 日目副機能検査（腎クリアランス）施行中, 覀心, 全身 脱力感, 四肢の泠感を訴え, 次第に増悪, 頻回の嘔吐を繰返しつつ嗜眠傾向となり血圧下降してショック状 態に陥つた．症例 2 . 当科受診前すでにネフローゼ症候群でステロイドを服用していたが，軽快せぬため入 院. 入院後初期療法として Prednisolone $40 \mathrm{mg} /$ 日， 4 週間使用後門歇維持療法に入るため一時, 治療を中 止したところ著明な頭痛, 筋肉痛, 関節痛, 悪心が発現した. 以上の二症例はいずれも副腎皮質ステロイド 
の再使用により軽快した。

\section{III-17 ヒト副腎静脈 catheterization による corticosterone 濃度測定の意義}

千葉大・泌尿器科 中田 愥浩, 百瀬 剛一, 吉田 豊彦

1967年 Melby がヒト副腎静脈へ catheterization し, 副腎静脈撮影とともに aldosterone 濃度を測定, 7 例の primary aldosteronism を発見するにおよび本法は，近年，にわかに注目をあびる様になつた，我 々は, 高血圧患者を主体に本法を施行し, 副腎静脈血中の corticosterone 濃度を測定し, 本 steroid 濃度と 副腎組織所見とを対比検討した。この両者の間に相関々係がある事を認め, 本 steroid の測定は副腎疾患の 診断に有用であると考えられる.

III-18 Triamcinolone acetonide 筋注後の血中濃度および尿中排泄率について

国立がんセンター ○草間 光俊, 坂内 昇, 熊岡 爽一

Triamcinolone acetonide (T-A) の筋注による臨床効果が長時間持続するととは気管支喘息，ネフロー ゼ症候群などでみられている。しかし，その血中の濃度の正確な報告は本剂が適当な呈色反応或いは螢光反

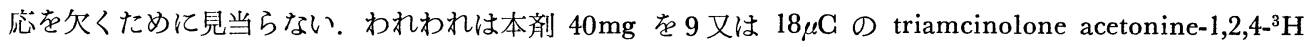
と共に筋注したのち血墏中の $\mathrm{T}-\mathrm{A}$ および triamcinolone (T) をメチレンクロライドで抽出し, TLC で 分離し, おのおのの放射能を測定し, その血中濃度を換算定量した。 5 例の測定で T-A $40 \mathrm{mg}$ 筋注後の平 均血中濃度は 3 時間で $51.7 \mu \mathrm{g} / 100 \mathrm{ml}$ を示し， 6 および14日目は $15 \mu \mathrm{g}, 21$ 日目には $5 \mu \mathrm{g}$ と減少したが，な ほ有効濃度であつた。血中 $\mathrm{T}$ 濃度は $\mathrm{T}-\mathrm{A}$ より著しく低く筋注 3 時間後 $5 \mu \mathrm{g}$ で 4 日目に $10 \mu \mathrm{g}$ の小さなピ 一クを示したのち再び $5 \mu \mathrm{g}$ 亿低下した．血中 cortisol 尿中 17-OHCS も $3 \sim 4$ 週間抑制された. T-A の 尿中排泄渠は 7 日間で1, 65\%と少く, 本剤が難溶性で筋注部位から血中への移行が緩徐であるととを示すと 思われる.

III-19＼cjkstart血漿中硫酸抱合型 Corticoids の分離, 同定

金沢大・第三内科 宮保 進

先に報告した尿中硫酸抱合型 Cortisol Metabolites の分離, 同定に続き, 血漿中の硫酸抱合型について検 討した. 正常人（11例）及び本態性高血圧患者（10例）に Gortisol-4-C ${ }^{14}$ を静注， 2 時間後に採血，除蛋白 した血漿及び Protein Cake につき, 酢酸エチルで遊離型を抽出後, Amberlite XAD-2 カラムで結合型を 溶出, 高圧濾紙電気泳動でグルクロン酸抱合, 硫酸抱合及び未知の抱合型に分離した. 硫酸抱合分画住 Solvolysis 後, 各種のペーパークロマトグラフイーの組合せにより, 個々の Cortisol Metabolites に分離 し, Reverse Isotopic Dilution 及び Derivative Formation により同定した. 結果 1) 尿中と同様, 血 漿中においても20種近い硫酸抱合型 Cortisol Metabolites を証明した。 2）グルクロン酸抱合分画に比し て, Cortols, Cortolones, ER, EpiER の如き Glycerol side chain を持つ metabolites の増加が特徵的で あつた． 3 ）本態性高血圧患者では硫酸抱合型（全抱合型の $8.34 \% ）$ が正常人（5.27\%）に比し，有意に增 加していだ

IV-1＼cjkstart最近経験した原発性アルドステロン症 3 例について

日大・第二内科 ○本多 正信, 小田 立男, 今田 聡雄, 未盛 英雄, 白土 晨寿 加藤 文朗

第 1 例，女性，36才．昭和 39 年第 2 児妊娠中高血圧症，尿蛋白，浮嗹をみ，40年頃より脱力感，口喝，多 尿が著明となり，低 $\mathrm{K}$ 血症，血漿レニン反応抑制，尿アルドステロン増加．右副腎に $1.2 \times 1.0 \mathrm{~cm}$ の腫煌 をみとめた，術後諸症状は消失した，第 2 例，女性，55才，四肢の脱力感を主訴とし，高血圧，低 $\mathrm{K}$ 血症 あり, 後腹膜気体撮影にて右腎上部に異常陰影あり, レニン反応抑制, 尿アルド増量. 右副腎に $2.0 \times 2.0$ $\mathrm{cm}$ の腫湯を発見術後諸症状の消失をみた．第 3 例，女性，32才．昭和 36 年第一子の妊娠中より高血圧，尿 蛋白出現, その後脱力感, 低 $\mathrm{K}$ 血症, 多尿を訴え, レニン反応抑制, 尿中アルド増量. 手術したが, 充分 の検索にもかかわらず，腫煌をみとめず，副腎の亜全瘍出を施行した，両側副副皮質球状首の diffuse hy- 
perplasia をみとめた，術後諸症状はやや改善されたが，充分でないのでアルダクトン等で治療中である.

IV-2 $18 \cdot \mathrm{OH} \cdot \mathrm{DOG}$ 短期投与の血圧，電解質および血漿 Renin 活性におよぼす

影響について

金沢大・村上内科 内田 健三，波佐谷兼綱，曰倉 教臣，西沢千恵子，能登 康夫

中林 肇, 平沢謙太郎, 森本 真平, 竹田 亮祐, 村上 元孝

前回の本学会において血圧, 電解質, 血漿 Renin 活性 (PRA) の変動わよび副腎コルチコイド分析パタ ーンから,ラットの副腎再生性高血圧における 18-OH-DOG の病因的役割を推測した，今回 18-OH-DOG の意義をより適確に検討する目的で，本ステロイド短期投与の PRA，麗解質におよぼす効果を DOC，Corticosterone のそれと比䡯した。 18-OH-DOG は DOG を前駆物質としラット副腎ホモデェネートを用い生 合成した。すすなわちラット副腎の NAOP, G-6-P 添加 “Sucrose homogenate” $100 \mathrm{mg} / 5 \mathrm{ml}$ あたり，DOC $1 \mathrm{mg}$ を加え $\mathrm{pH} 7.4,37^{\circ}$ で 2 時間インクベートし，メデウムの鏡エス・エキスを薄層クロマトにかけ，18. OH-DOG を分離，精製した，ステロイド投与は持続注入装置を用い，副腎摘出ラットに $0.022 \mathrm{ml} / \mathrm{min}$ で 3 時間静脈内注入した，注入前後の血圧，PRA，電解質の変動を検討した結果，血圧に著しい変化はみとめ なかつたが，DOG，18-OH-DOG では PRA の抑制がみとめられた。

IV-3 原発性 aldosterone 症における aldosterone 分泌の諸相, 特に DOCA 投与時の aldosterone 分泌量について

東北大・鳥飼内科 勝島 一郎

Aldosterone 分泌量 (ASR) 測定により,より有効に原発性 aldosterone 症を識別しうる条件を発見す る目的で，諸条件下での本症の ASR を測定し検討した。本症15例20回の前值は70〜650 $\mu \mathrm{g} /$ 日に分布した。 内 $70 \mu \mathrm{g} /$ 日の男子例は絶対值では正常範国内 (12 $89 \mu \mathrm{g} /$ 日, $\mathrm{n}=16)$ にあつたが，黄体期女子を除外し，且 $\mathrm{Na}$ 排泄量との相関のもとに設定した正常域からは識別された。健常女子 5 例中 4 例で黄体期の ASR は卵 胞期の約 2 倍に上昇したが，本症の女子 6 例では平均 $22 \%$ 上昇をみた。DOGA $20 \mathrm{mg} 4$ 日筋注により， 13例中11例（85\%）でASR は上昇した（平均上昇率46\%)。全13例の前值 70〜522（平均 201），DOGA 筋 注時 135〜740 (268) $\mu \mathrm{g} /$ 日で，乙とに下限の上昇が注目された。一方 8 例で Sodium deprivation 前後の ASR を測定したが，上昇下降相半ばし分布範囲は上下に抆大した。 以上の結果から，より鋭敏に本症を識 別するには，測定時の性週期及び Na 排泄量を考虑すべきであり，殊に DOGA 投与時の測定は極めて有 意義と考えられる.

IV-4＼cjkstart立位負荷時の血漿アンギオテンシン含量測定による高血圧の鑑別診断

東北大・鳥飼内科 福地 総逸, 勝島 一郎

諸種高血圧症にわけるレニン・アンギオテンシンの動態を知る目的で実験を行つた．まず早朝空腹時安静 臥床の上，股動脈より採血して後，2 時間立位にし，その後再び股動脈より採血した. 血漿アンギオテンシ ン含量はすでに発表した Radioimmunoassay により測定した．原発性アルドステロン症の前值は 14-18pg/ $\mathrm{ml}$ と低く，立位によつても上昇しなかつた。術後はすべての例で前值が上昇したが，術後 1 ケ月目までは 立位による上昇度が軽度であつた．筒血管性高血圧症の前值は 46-96pg/ $/ \mathrm{ml}$ と正常値を示したが，立位によ り著明に上昇した。特に片側性腎動脈狭窄例において著明であつた。手術後には著明に低下したが，立位に よつては術後においても上昇するてとが認められた。本態性高血圧症の前値は $32-116 \mathrm{pg} / \mathrm{ml}$ で，立位負荷 により軽度に上昇した．以上の成績は立位負荷によりてれらの高血圧症の鑑別が可能であるととを示してい З 